\title{
Fish fauna from Sapucaí-Mirim River, tributary of Grande River, upper Paraná River basin, Southeastern Brazil
}

\author{
Alexandre Kannebley de Oliveira ${ }^{1,4}$, Julio Cesar Garavello ${ }^{2}$, Vinicius Vendramini Cesario ${ }^{3}$ \& \\ Rodrigo Torres Cardoso ${ }^{3}$ \\ ${ }^{1}$ Universidade Federal de São Carlos, Departamento de Ciências Ambientais, Rod. Washington Luis Km 235, \\ São Carlos, SP, Brazil. \\ ${ }^{2}$ Universidade Federal de São Carlos, Departamento de Ecologia e Biologia Evolutiva, \\ São Carlos, SP, Brazil. \\ ${ }^{3}$ Universidade Federal de São Carlos, Programa de Pós Graduação em Ecologia e Recursos Naturais, \\ São Carlos, SP, Brazil. \\ ${ }^{4}$ Corresponding author: Alexandre Kannebley de Oliveira, e-mail: pako@ufscar.br.
}

OLIVEIRA, A.K., GARAVELLO, J.C., CESARIO, V.V., CARDOSO, R.T. Fish fauna from Sapucaí-Mirim River, tributary of Grande River, upper Paraná River basin, Southeastern Brazil. Biota Neotropica. 16(1): e20140192. http://dx.doi.org/10.1590/1676-0611-BN-2014-0192

\begin{abstract}
The fish species composition of Sapucaí-Mirim River is herein reported and discussed in the faunistic context of Grande and Paranaíba river basins, both formers of the Paraná River. The SapucaíMirim is an important tributary of this hydrographic system, flowing to the left bank of Grande River in a region occupied by the reservoir of the Porto Colombia hydroelectric power plant, at São Paulo state northeastern region, in southeastern Brazil. The poorly known fish diversity of the Sapucaí-Mirim River is presented on basis of sampling efforts conducted in the main river channel and three creeks located at the mid and lower sections of the basin, allowing comparisons of the fish fauna of these two sections in the light of available information of fish inhabiting Grande and Paranaíba river basins. The study of the fish composition resulted in the recognition of 68 species in the Sapucaí-Mirim River, belonging to 23 families distributed in seven orders, all commonly found in upper Paraná River basin: Characiformes (32 spp.), Siluriformes (25 spp.), Labriformes (4 spp.), Gymnotiformes (3 spp.), Cyprinodontiformes (2 spp.), Perciformes (one species) and Synbranchiformes (one species). Most of the species are representative of the native ichthyofauna, but the total diversity also includes allochthonous species, which were chiefly found in the lower stretch studied. Some species found in the Sapucaí-Mirim River require great areas for their maintenance, as do large-sized species, known to have migratory reproductive habits. Also, the diversity of small and medium-sized species found and their distinct morphological and biological attributes, allied to the occurrence of endangered fish species, indicate that the Sapucaí-Mirim River basin is an important place for fish diversity maintenance in the Grande River hydrographic system.
\end{abstract}

Keywords: Neotropical region, freshwater fishes, composition, biodiversity, spatial distribution.

OliveirA, A.K., GARAVEllo, J.C., CESARIO, V.V., CARDOSO, R.T. Fauna de Peixes do rio Sapucá-Mirim, tributário do rio Grande, bacia do alto rio Paraná, sudeste do Brasil. Biota Neotropica. 16(1): e20140192. http://dx.doi.org/10.1590/1676-0611-BN-2014-0192

Resumo: A composição de espécies de peixes do rio Sapucaí-Mirim é registrada e discutida no âmbito do conjunto faunístico das bacias dos rios Grande e Paranaíba, ambos formadores do rio Paraná, no sudeste do Brasil. O rio Sapucaí-Mirim é um importante, mas pouco conhecido tributário deste sistema hidrográfico, desembocando na margem esquerda do rio Grande, na área atualmente ocupada pelo reservatório da Usina Hidrelétrica de Porto Colômbia, na região nordeste do estado de São Paulo. A diversidade de peixes do rio Sapucaí-Mirim é apresentada com base em dados comparativos obtidos de populações do canal principal do rio e de três córregos localizados nos trechos médio e inferior da bacia, possibilitando uma discussão comparativa entre os dois trechos a luz de informações existentes sobre a fauna de peixes das bacias dos rios Grande e Paranaíba. O estudo da fauna de peixes resultou no reconhecimento de 68 espécies de peixes distribuídas em 23 famílias e pertencentes às sete ordens comumente encontradas na bacia do alto rio Paraná: Characiformes (32 spp.), Siluriformes (25 spp.), Labriformes (4 spp.), Gymnotiformes (3 spp.), Cyprinodontiformes (2 spp.), Perciformes (1 espécie) e Synbranchiformes (1 espécie). A maioria das espécies é representativa da ictiofauna nativa distribuída nos rios Grande e Paranaíba, mas a diversidade total também inclui espécies alóctones, registradas 
principalmente no trecho inferior. Algumas espécies encontradas no rio Sapucaí-Mirim requerem grandes áreas para sua manutenção, tais como aquelas de grande porte, conhecidas por apresentarem hábitos reprodutivos migratórios. Também, a diversidade de espécies de pequeno e médio porte e seus diferentes atributos biológicos exibidos, aliados ao registro de espécies ameaçadas na bacia do alto rio Paraná, permitem considerar a bacia do rio Sapucaí-Mirim como um importante local para manutenção da diversidade da ictiofauna no sistema hidrográfico do rio Grande.

Palavras-chave: Região Neotropical, peixes de água doce, composição, biodiversidade, distribuição espacial.

\section{Introduction}

The Sapucaí-Mirim River, situated in northeastern of the São Paulo State, is part of a great drainage area in the upper Paraná River basin that includes the rivers Grande, Pardo and Mogi-Guaçu, three basins that have their fish fauna relatively well known, in comparison with other regions of South America. In fact, this is a region where naturalists have been gathering information and documenting the fish fauna since early XIX century, when Johann Natterer collected specimens of the ichthyofauna that were studied and described by European naturalists (Heckel 1840, Vanzolini, 1993). Initially, until near the 1930s, the studies focused on collecting and describing the species. Later, studies covered up many ichthyological subjects, including lists of species in some areas, descriptions on the species diversity, and studies on biology and ecology of fish populations (see Godoy 1975, Castro \& Casatti 1997, Santos \& Formagio 2000, Oliveira \& Garavello 2003, Birindelli \& Garavello 2005, Apone et al. 2008, Oliveira et al. 2009 for overview about those studies).

Although there is significant amount of information on the fish fauna of the upper Paraná River basin, some areas within this drainage lack studies on ichthyological diversity, which represent gaps on the knowledge of species distribution and restrict comparisons with areas already studied. The SapucaíMirim River basin represents one of these little-documented areas and, as other rivers in the upper Paraná basin, is actually been sectioned by hydroelectric power plant dams. Castro et al. (2004) have inventoried small tributaries of the Sapucaí-Mirim River in a broader study about streams fish composition of the Grande River basin, but Casatti et al. (2008) stated that the Sapucaí-Grande is one of the management units of hydric resources in São Paulo State that still need sampling efforts for a better understanding of its fish fauna. A report on the fish fauna composition and structure before the reservoirs had been filled is welcome, since it allows posterior comparative studies and is useful as basis for fish management and conservancy.

In view of the deficiency of information mentioned above and the continuous environmental changes, chiefly the damming process, a study on fish fauna composition and structure in the middle and lower stretches of Sapucaí-Mirim River basin, near the municipalities of São Joaquim da Barra and Guaíra respectively, is herein presented. Fish assemblages from the main channel and three creeks of these two stretches of the Sapucaí-Mirim River basin are reported and their role on the ichthyofaunistic diversity of upper Paraná River system, particularly in Grande and Paranaíba River basins, is discussed.

\section{Material and Methods}

\section{Study area}

The Sapucaí-Mirim River has its headwaters near the crystalline shield of Serra da Laje, at approximately 1,150 m of altitude, in the inland slope of mountains situated near the boundary of the northeastern São Paulo and Minas Gerais states. The drainage is geologically located near the East border of the Paraná Province, on the Serra Geral Basin (Silva et al. 2003). It is a medium-sized Brazilian river with strong riffles and small waterfalls intercalated by runs in its mid course, changing into slow waters and without turbulence in the lower region, where it meets and receives the influence of the lentic waters of the UHE Porto Colombia reservoir, in Grande River. As component of the large aquatic complex of the Grande River, the Sapucaí-Mirim River can be considered among the few rivers from Southeast Brazilian region that remained with its original hydric characteristics relatively preserved until the beginning of the XXI century. In fact, the main Sapucaí-Mirim River channel presented until near 2010 only two small centennial hydroelectric power station: the São Joaquim (previously called Evangelina) Station, constructed in 1911, and Dourados Station, from 1926, both located upstream to the areas herein studied, and thus remaining a river dam free long stretch downstream till the Sapucaí-Mirim River mouth in the Grande River.

Fish sampling were performed at two sites of the SapucaíMirim River, one in its mid stretch (approximate coordinate $20^{\circ} 29^{\prime} 49^{\prime \prime} \mathrm{S}$ and $47^{\circ} 51^{\prime} 50^{\prime \prime} \mathrm{W}$ ), at the municipality of São Joaquim da Barra, and other in the lower stretch of the drainage, at Guaíra municipality (approximate coordinate $20^{\circ} 11^{\prime} 43^{\prime \prime} \mathrm{S}$ and $48^{\circ} 15^{\prime} 15^{\prime \prime} \mathrm{W}$ ), at São Paulo State (Figure 1).

The section near São Joaquim da Barra is characterized as a lotic environment, with cobblestones and sand, strongly typifying a rapid with rocky floor large cataracts and small falls, with depth not surpassing three meters deep at the deepest places. This section includes few navigate areas, with lower water velocity and deeper pools, showing short sand areas in the banks with marginal vegetation, thus representing most of the original features of this river.

The section near the municipality of Guaíra has other hydrological characteristics. This area presents running waters without rapids as observed in the middle section. At this area the depth reach up to six meters or more at some great pools, allowing navigation in the Sapucaí-Mirim River downstream to Porto Colombia reservoir. With sandy bottom and preserved banks vegetation, this section of Sapucaí-Mirim is under influence of the reservoir waters. From this place to the large reservoir, where its waters flow, one can observe that there are relatively small variations on the river depth and more homogenous environmental features in comparison with the middle section.

Additionally, three creeks of the Sapucaí-Mirim River basin were sampled in the species inventory. Two of them are left bank tributaries in the mid stretch region (Barra Creek and Imbaúba Creek), near São Joaquim da Barra municipality, and the third (Corta Pescoço Creek) is also a left bank affluent, but located in the lower stretch of the Sapucaí basin, near Guaíra municipality. The sampled stretches of the creeks were located near their mouth within Sapucaí-Mirim and characterized by 


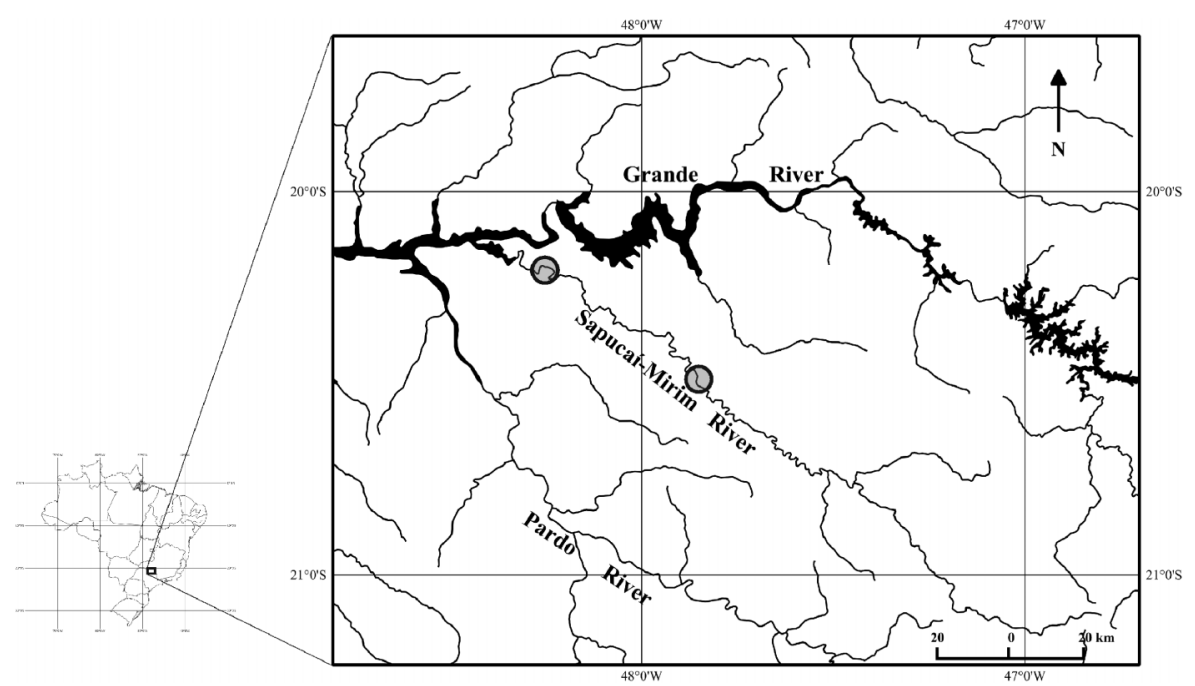

Figure 1. Map showing location of Sapucaí-Mirim River in Grande River basin. Grey circles show the mid and lower studied stretches in the Sapucaí-Mirim River, São Paulo State.

Figura 1. Mapa mostrando a localização do Rio Sapucaí-Mirim na bacia do rio Grande. Círculos em cinza mostram os trechos, médio e baixo, estudados no rio Sapucaí-Mirim, Estado de São Paulo.

sandy bottom pools and runs with moderate water velocity. The creeks are inserted in areas predominantly occupied by sugar cane culture, but their margins presented herbaceous vegetation, shrubs and trees along the sampled stretches.

\section{Fish sampling and analysis}

The ichthyofauna of the Sapucaí-Mirim River was characterized based on fish samplings performed in the main channel and creeks, in different periods. The main river channel at mid stretch was sampled in June 2004, in January, July, August and October 2008, and in February 2009. The lower stretch was sampled in July 2007, January 2008, and in April and June 2009. In these field surveys, fish were caught using gill nets ( $20 \mathrm{~m}$ length, 15 to $80 \mathrm{~mm}$ mesh between adjacent knots, installed in the evening and standing in the water for approximately 12 hours until the early morning of next day), casting nets and a small seine net $(3 \mathrm{~m}$ length and $3 \mathrm{~mm}$ mesh). Each fishing gear was applied in appropriate places along the sampled stretch, so gill nets were used in deeper pools, and active fishery gears were applied in shallow places, as small sand beaches, in rapids and under the river bank vegetation. The creeks were sampled in August and October 2008, and in April 2009, using the small $3 \mathrm{~mm}$ mesh seine net in stretches located near their mouth within the Sapucaí-Mirim River.

Sampled fishes had their standard length $(\mathrm{mm})$ measured, except Gymnotiformes and Synbranchiformes species, from which total length were registered. All fish specimens collected in the creeks were immediately fixed in $10 \%$ formalin, as do some voucher specimens caught in main river channel. In the laboratory the fixed specimens were transferred to a solution of ethanol 70\%. Voucher specimens are deposited at the Laboratório de Ictiologia Sistemática da UFSCar (LISDEBE) fish collection under numbers LISDEBE 2140-2163, 2298-2350, 4058-4103, 4309-4377, 4461-4464, 4839 and 6112. Fish species identification was based on comparative ichthyological material from LISDEBE and on consulting specific taxonomic and systematic literature of fish groups. Systematic classification follows Reis et al. (2003) and updated information according to Van der Laan et al. (2014) and Wiley \& Johnson (2010), who classified the
Cichlidae family as part of Labriformes order. Some species were identified as non-native following Langeani et al. (2007).

The maximum body size of the species were separated in seven classes, following Sturges (1926), to construction of a frequency of occurrence graph and characterization of the body size structure of fish assemblage in the Sapucaí-Mirim River. Body size and fish ecological traits are discussed from the knowledge of the actual ichthyological scenario of the Grande River basin.

\section{Results}

The inventory of fish fauna from Sapucaí-Mirim River basin resulted in the identification of 68 species from the collection of 2132 specimens. The species belong to the seven fish orders originally found in upper Paraná River: Characiformes, Siluriformes, Gymnotiformes, Cyprinodontiformes, Synbranchiformes, Labriformes and Perciformes. Characiformes summed 32 species distributed in 10 families: Characidae (11 species), Anostomidae (seven species), Parodontidae and Serrasalmidae (three species each), Curimatidae and Bryconidae (two species), and Crenuchidae, Acestrorhynchidae, Erythrinidae and Prochilodontidae (with one species each). Siluriformes presented 25 species distributed in seven families: Loricariidae (11 species), Heptapteridae (four species), Pimelodidae (four species), Callichthyidae (3 species), and Doradidae, Pseudopimelodidae and Auchenipteridae (a single species each). Labriformes presented four species (all of the family Cichlidae). Gymnotiformes were represented by three species of the families Apteronotidae, Sternopygidae and Gymnotidae (each with a single species). Cyprinodontiformes presented two species of the family Poeciliidae. Perciformes and Synbranchiformes presented one species each, of the families Sciaenidae and Synbranchidae, respectively. Of the 68 inventoried species, 61 were registered in the main river channel (Table 1) and 17 were registered in the creeks (Table 2).

In the main river channel, the middle section at São Joaquim da Barra revealed 51 species, and the lower section of the river, at the area of Guaíra, showed 38 species (Table 1). From the 61 collected species in the river main channel habitats, $28(46 \%)$ were common to both basin stretches. The 
Table 1. Species list, number of specimens, and body size (minimum and maximum in $\mathrm{mm}$ ) of the fish species registered in the main river channel at the two studied sections (mid and lower stretches) of Sapucai-Mirim River basin, in São Paulo State. Voucher represents the register number of lots deposited in LISDEBE fish collection (X - species from which fish specimens were not deposited in collection but identified and measured during field work).

Tabela 1. Lista de espécies, número de espécimes, e tamanho de corpo (mínimo e máximo em mm) das espécies de peixes registradas na calha principal nas duas seções estudadas (trechos médio e inferior) na bacia do rio Sapucaí-Mirim, no estado de São Paulo. Voucher representa os números de tombo dos lotes depositados na coleção de peixes do LISDEBE (X - espécies cujos espécimes não foram depositados em coleção, mas identificados e medidos durante os trabalhos de campo).

\begin{tabular}{|c|c|c|c|c|c|c|c|}
\hline & \multicolumn{3}{|c|}{ Mid stretch } & \multicolumn{3}{|c|}{ Lower stretch } & \multirow[b]{3}{*}{ Voucher } \\
\hline & \multirow[b]{2}{*}{$\mathbf{N}$} & \multicolumn{2}{|c|}{ body size (mm) } & \multirow[b]{2}{*}{$\mathbf{N}$} & \multicolumn{2}{|c|}{ body size (mm) } & \\
\hline & & $\min$. & $\max$ & & min. & $\max$. & \\
\hline \multicolumn{8}{|l|}{ Characiformes } \\
\hline \multicolumn{8}{|l|}{ Parodontidae } \\
\hline Apareiodon affinis (Steindachner, 1879) & 20 & 102.0 & 146.0 & 0 & & & 4324 \\
\hline Apareiodon piracicabae (Eigenmann, 1907) & 16 & 33.7 & 125.8 & 0 & & & 4340 \\
\hline Parodon nasus Kner, 1859 & 22 & 64.3 & 135.0 & 0 & & & 4364 \\
\hline \multicolumn{8}{|l|}{ Curimatidae } \\
\hline Cyphocharax modestus (Fernándes-Yépez, 1948) & 3 & 85.0 & 117.0 & 0 & & & $\mathrm{X}$ \\
\hline Steindachnerina insculpta (Fernández-Yépez, 1948) & 86 & 80.0 & 123.0 & 40 & 80.0 & 125.0 & 4090 \\
\hline \multicolumn{8}{|l|}{ Prochiolodontidae } \\
\hline Prochilodus lineatus (Valenciennes, 1837) & 13 & 134.0 & 393.0 & 2 & 101.0 & 144.0 & 4463 \\
\hline \multicolumn{8}{|l|}{ Anostomidae } \\
\hline Leporinus amblyrhynchus Garavello \& Britski, 1987 & 13 & 108.0 & 221.8 & 0 & & & 4362 \\
\hline Leporinus obtusidens Valenciennes, 1837 & 1 & 198.0 & & 1 & 320.0 & & 4319 \\
\hline Leporinus aff. friderici (Bloch, 1794) & 29 & 145.0 & 320.0 & 34 & 120.6 & 353.0 & 4367 \\
\hline Leporinus lacustris Amaral Campos, 1945 & 0 & & & 2 & 143.0 & 164.0 & 2301 \\
\hline Leporinus octofasciatus Steindachner, 1915 & 15 & 97.0 & 245.0 & 2 & 188.0 & 228.0 & 4366 \\
\hline Leporinus striatus Kner, 1858 & 8 & 97.0 & 109.0 & 1 & 102.2 & & 4361 \\
\hline Schizodon nasutus Kner, 1858 & 5 & 226.0 & 335.0 & 13 & 145.0 & 359.0 & 4464 \\
\hline \multicolumn{8}{|l|}{ Erythrinidae } \\
\hline Hoplias cf. malabaricus (Bloch, 1794) & 1 & 291.0 & & 11 & 144.5 & 357.0 & 2148 \\
\hline \multicolumn{8}{|l|}{ Acestrorhynchidae } \\
\hline Acestrorhynchus lacustris (Lütken, 1875) & 0 & & & 1 & 140.0 & & $\mathrm{X}$ \\
\hline \multicolumn{8}{|l|}{ Serrasalmidae } \\
\hline Metynnis maculatus (Kner, 1858) & 5 & 75.0 & 123.1 & 3 & 90.0 & 105.9 & 4096 \\
\hline Myleus tiete (Eigenmann \& Norris, 1900) & 0 & & & 1 & 275.0 & & 4318 \\
\hline Serrasalmus maculatus Kner, 1858 & 0 & & & 2 & 67.7 & 88.1 & 2150 \\
\hline \multicolumn{8}{|l|}{ Characidae } \\
\hline Astyanax altiparanae Garutti \& Britski, 2000 & 212 & 64.0 & 169.0 & 36 & 63.0 & 125.0 & 4091 \\
\hline Astyanax fasciatus (Cuvier, 1819) & 340 & 72.0 & 147.0 & 19 & 68.0 & 122.4 & 4088 \\
\hline Astyanax schubarti Britski, 1964 & 3 & 82.4 & 130.2 & 6 & 63.5 & 69.2 & 2154 \\
\hline Astyanax bockmanni Vari \& Castro, 2007 & 45 & 16.0 & 83.0 & 0 & & & 4328 \\
\hline Bryconamericus stramineus Eigenmann, 1908 & 12 & 18.1 & 74.8 & 0 & & & 4085 \\
\hline Bryconamericus sp. & 7 & 24.7 & 44.4 & 0 & & & 4086 \\
\hline Galeocharax knerii (Steindachner, 1879) & 12 & 133.0 & 245.0 & 25 & 132.7 & 165.0 & 4327 \\
\hline Piabina argentea Reinhardt, 1867 & 5 & 54.1 & 94.0 & 0 & & & 4083 \\
\hline \multicolumn{8}{|l|}{ Bryconidae } \\
\hline Salminus brasiliensis (Cuvier, 1816) & 1 & 480.0 & & 1 & 364.0 & & 2146 \\
\hline Salminus hilarii Valenciennes, 1850 & 19 & 124.0 & 317.0 & 9 & 104.3 & 242.0 & 4462 \\
\hline \multicolumn{8}{|l|}{ Siluriformes } \\
\hline \multicolumn{8}{|l|}{ Doradidae } \\
\hline Rhinodoras dorbignyi (Kner, 1855) & 1 & 220.0 & & 4 & 90.0 & 143.0 & 2304 \\
\hline \multicolumn{8}{|l|}{ Auchenipteridae } \\
\hline Glanidium cesarpintoi Ihering, 1928 & 1 & 87.6 & & 0 & & & 2349 \\
\hline Pimelodidae & & & & & & & \\
\hline Iheringichthys labrosus (Lütken, 1874) & 4 & 133.0 & 164.0 & 0 & & & 4330 \\
\hline Pimelodus microstoma Steindachner, 1877 & 32 & 114.0 & 326.0 & 0 & & & 4375 \\
\hline Pimelodus maculatus Lacépède, 1803 & 0 & & & 10 & 245.0 & 342.0 & 2305 \\
\hline Pimelodus sp. & 0 & & & 1 & 193.0 & & 2327 \\
\hline
\end{tabular}




\begin{tabular}{|c|c|c|c|c|c|c|c|}
\hline & & Mid str & & & Lower $\mathbf{s}$ & & \\
\hline & & body & $(\mathrm{mm})$ & & body & $(\mathbf{m m})$ & \\
\hline & $\mathbf{N}$ & $\min$. & $\max$. & $\mathbf{N}$ & $\min$. & $\max$. & Voucher \\
\hline Pseudopimelodidae & & & & & & & \\
\hline Pseudopimelodus mangurus (Valenciennes, 1835) & 1 & & 453.0 & 1 & 115.3 & & 4377 \\
\hline Heptapteridae & & & & & & & \\
\hline Imparfinis schubarti (Gomes, 1956) & 5 & 98.2 & 107.0 & 0 & & & 4341 \\
\hline Pimelodella cf. gracilis (Valenciennes, 1835) & 20 & 92.7 & 134.6 & 0 & & & 2316 \\
\hline Rhamdia quelen (Quoy \& Gaimard, 1824) & 17 & 113.0 & 287.0 & 4 & 192.0 & 263.0 & 2325 \\
\hline Callichthyidae & & & & & & & \\
\hline Callichthys callichthys (Linnaeus, 1758) & 0 & & & 3 & 175.0 & 194.0 & $\mathrm{X}$ \\
\hline Hoplosternum littorale (Hancock, 1828) & 5 & 148.0 & 201.0 & 8 & 124.0 & 186.0 & 4310 \\
\hline Megalechis thoracata (Valenciennes, 1840) & 1 & 122.0 & & 29 & 118.0 & 147.0 & 2299 \\
\hline Loricariidae & & & & & & & \\
\hline Hypostomus ancistroides (Ihering, 1911) & 76 & 15.0 & 130.0 & 39 & 74.7 & 124.0 & 4087 \\
\hline Hypostomus heraldoi Zawadzki, Weber \& Pavanelli, 2008 & 62 & 100.0 & 270.0 & 0 & & & 4101 \\
\hline Hypostomus cf. margaritifer (Regan, 1908) & 102 & 103.0 & 270.0 & 4 & 151.0 & 204.0 & 2335 \\
\hline Hypostomus nigromaculatus (Schubart, 1964) & 3 & 54.9 & 64.5 & 0 & & & 2333 \\
\hline Hypostomus paulinus (Ihering, 1905) & 114 & 62.0 & 154.0 & 6 & 104.0 & 142.0 & 4355 \\
\hline Hypostomus regani (Ihering, 1905) & 97 & 73.0 & 246.0 & 14 & 99.8 & 198.0 & 4358 \\
\hline Hypostomus cf. strigaticeps (Regan, 1908) & 81 & 65.0 & 204.0 & 4 & 125.0 & 224.0 & 4357 \\
\hline Hypostomus sp. A & 13 & 55.0 & 130.0 & 11 & 74.6 & 123.0 & 4322 \\
\hline Hypostomus sp. B & 7 & 120.0 & 142.0 & 0 & & & 4373 \\
\hline Loricaria lentiginosa Isbrücker, 1979 & 21 & 152.0 & 390.0 & 11 & 172.0 & 371.0 & 4376 \\
\hline Rineloricaria latirostris (Boulenger, 1900) & 21 & 100.8 & 135.3 & 3 & 116.7 & 133.3 & 4344 \\
\hline Gymnotiformes & & & & & & & \\
\hline Sternopygidae & & & & & & & \\
\hline Eigenmannia virescens (Valenciennes, 1836) & 7 & 183.0 & 262.0 & 0 & & & 2323 \\
\hline Apteronotidae & & & & & & & \\
\hline Apteronotus brasiliensis (Reinhardt, 1852) & 1 & 298.0 & & 0 & & & 4097 \\
\hline Gymnotidae & & & & & & & \\
\hline Gymnotus sp. & 3 & 373.0 & & 0 & & & 4321 \\
\hline Cyprinodontiformes & & & & & & & \\
\hline Poeciliidae & & & & & & & \\
\hline Phalloceros harpagos Lucinda, 2008 & 5 & 15.2 & 24.0 & 0 & & & 4080 \\
\hline Synbranchiformes & & & & & & & \\
\hline Synbranchidae & & & & & & & \\
\hline Synbranchus marmoratus Bloch, 1795 & 1 & 200.0 & & 0 & & & $\mathrm{X}$ \\
\hline Perciformes & & & & & & & \\
\hline Sciaenidae & & & & & & & \\
\hline Plagioscion squamosissimus (Heckel, 1840) & 0 & & & 46 & 159.0 & 373.0 & 2142 \\
\hline Labriformes & & & & & & & \\
\hline Cichlidae & & & & & & & \\
\hline Crenicichla jaguarensis Haseman, 1911 & 0 & & & 3 & 143.9 & 161.0 & 2140 \\
\hline Geophagus brasiliensis (Quoy \& Gaimard, 1824) & 15 & 19.1 & 161.0 & 0 & & & 4081 \\
\hline Satanoperca pappaterra $($ Heckel, 1840) & 0 & & & 1 & 154.0 & & 2141 \\
\hline Richness & 51 & & & 38 & & & \\
\hline Total abundance & 1609 & & & 411 & & & \\
\hline
\end{tabular}

collection sites near the cataracts and waterfalls, in the mid stretch, showed higher specific richness, presenting also more fish families (20 families vs. 15 families in the lower stretch). More species per family were registered in the mid stretch, except for the families Serrasalmidae, Callichthyidae, Cichlidae and Sciaenidae. All Gymnotiform families were only registered in this richest middle stretch. Loricariidae (with 11 species in the mid vs. 8 species in lower stretch) and Characidae (with 8 species in the mid vs. 4 species in lower stretch) were the most species-rich families in the main river channel. Four registered species in the main river channel are considered non-native for the upper Paraná River basin: Metynnis maculatus (Kner, 1858), Satanoperca pappaterra (Heckel, 1840) and Plagioscion squamosissimus (Heckel, 1840) were found only in the lower stretch near the municipality of Guaíra, whereas Megalechis thoracata (Valenciennes, 1840) was present in both stretches.

Of the 17 species registered in the three creeks, seven species were found exclusively in this kind of environment: Astyanax aff. 
paranae Eigenmann, 1914, Cheirodon stenodon Eigenmann, 1915, Hyphessobrycon eques (Steindachner, 1882), Characidium aff. zebra Eigenmann, 1909, Cetopsorhamdia iheringi Schubart \& Gomes, 1959, Poecilia reticulata Peters, 1859 and Laetacara aff. araguaiae Ottoni \& Costa, 2009 (Table 2). Of these, Poecilia reticulata is nonnative for the basin. The species richness in the creeks ranged from three species in the Imbaúba Creek to nine species in the Barra Creek, summing 11 species in these creeks from mid section of the basin. The Corta Pescoço Creek located in the lower portion of the Sapucaí-Mirim drainage, presented 7 species (Table 2).

The range of the species maximum body size $(23 \mathrm{~mm}$ in Poecilia reticulata to $480 \mathrm{~mm}$ in Salminus brasiliensis (Cuvier, 1816)) encloses part of the different biological characteristics exhibited by the fish diversity found in the Grande River basin. The frequency distribution of the maximum body size classes of the fish species inventoried (Figure 2) showed that the majority of the species are small sized (with less than $200 \mathrm{~mm} \mathrm{SL}$ ), but species that reach medium (up to $400 \mathrm{~mm} \mathrm{SL}$ ) to great size (> $400 \mathrm{~mm}$ ) were also registered. Small characids, crenuchids, cyprinodontiforms, heptapterids are examples of those smallsized species
(Tables 1 and 2). Medium sized are represented by serrasalmids, characins, loricariids and some anostomids (Table 1). Large sized species includes those normally considered migratory native species, such as Salminus brasiliensis, Leporinus obtusidens Valenciennes, 1837 and Prochilodus lineatus (Valenciennes, 1837), and other non-migratory species, such as Loricaria lentiginosa Isbrücker, 1979 and Hoplias cf. malabaricus (Bloch, 1794).

\section{Discussion}

The fish fauna of the Sapucaí-Mirim River was chiefly composed by native species of the upper Paraná River drainage, comprising the six fish orders historically assigned for this basin. We classified the fish species in seven orders, following Wiley \& Johnson (2010) and considering the Cichlidae family in the Labriformes order, although this is traditionally reported as a family member of the Perciformes order. The dominance of Characiformes and Siluriformes in species richness reflects the ichthyofaunistic diversity of the Neotropical region, where these and the other ostariophysan order Gymnotiformes are the most

Table 2. Species list and number of specimens registered in the tree creeks sampled in two sections (mid and lower stretches) of the Sapucaí-Mirim River basin, in São Paulo State. Barra Creek and Imbaúba Creek are of the mid stretch; Corta Pescoço Creek flow to lower stretch. Body size (minimum and maximum in $\mathrm{mm}$ ) and voucher lots of LISDEBE fish collection are also presented.

Tabela 2. Lista de espécies e número de espécimes registrados nos três córregos amostrados em duas seções (trechos médio e inferior) da bacia do rio Sapucaí-Mirim, no Estado de São Paulo. Córregos da Barra e Córrego Imbaúba são afluentes do trecho médio da bacia; Córrego Corta Pescoço é afluente do trecho inferior. Tamanhos de corpo (mínimo e máximo em mm) e lotes testemunhos da coleção de peixes do LISDEBE (Voucher) também são apresentados.

\begin{tabular}{|c|c|c|c|c|c|c|}
\hline & \multirow{2}{*}{$\frac{\text { Barra }}{\text { Creek }}$} & \multirow{2}{*}{$\frac{\text { Imbaúba }}{\text { Creek }}$} & \multirow{2}{*}{$\frac{\text { Corta Pescoço }}{\text { Creek }}$} & \multicolumn{2}{|c|}{ Body Size (mm) } & \multirow[t]{2}{*}{ Voucher } \\
\hline & & & & $\min$. & $\max$. & \\
\hline \multicolumn{7}{|l|}{ Characiformes } \\
\hline \multicolumn{7}{|l|}{ Characidae } \\
\hline Astyanax fasciatus (Cuvier, 1819) & 1 & & 2 & 32.8 & 33.4 & 4068 \\
\hline Astyanax aff. paranae Eigenmann, 1914 & & 5 & & 31.5 & 39.2 & 4078 \\
\hline Astyanax schubarti Britski, 1964 & & & 1 & 42.7 & & 4059 \\
\hline Bryconamericus stramineus Eigenmann, 1908 & & & 3 & 33.7 & 41.5 & 4060 \\
\hline Bryconamericus sp. & & & 9 & 22.9 & 32.8 & 4062 \\
\hline Cheirodon stenodon Eigenmann, 1915 & & & 27 & 16.7 & 24.2 & 6112 \\
\hline Hyphessobrycon eques (Steindachner, 1882) & & & 15 & 13.5 & 28.1 & 4058 \\
\hline Piabina argentea Reinhardt, 1867 & 16 & & & 28.4 & 56.5 & 4071 \\
\hline \multicolumn{7}{|l|}{ Crenuchidae } \\
\hline Characidium aff. zebra Eigenmann, 1909 & 2 & & & 53.0 & 54.4 & 4074 \\
\hline \multicolumn{7}{|l|}{ Heptapteridae } \\
\hline Cetopsorhamdia iheringi Schubart \& Gomes, 1959 & 1 & & & 41.0 & & 4072 \\
\hline Imparfinis schubarti (Gomes, 1956) & 1 & & & 53.1 & & 4075 \\
\hline Pimelodella $\mathrm{cf}$. gracilis (Valenciennes, 1835) & 1 & & & 103.7 & & 4066 \\
\hline \multicolumn{7}{|l|}{ Loricariidae } \\
\hline Hypostomus ancistroides (Ihering, 1911) & 7 & 3 & & 16.5 & 96.4 & 4076 \\
\hline \multicolumn{7}{|l|}{ Gymnotiformes } \\
\hline \multicolumn{7}{|l|}{ Sternopygidae } \\
\hline Eigenmannia virescens (Valenciennes, 1836) & & 1 & & 246.0 & & 4079 \\
\hline \multicolumn{7}{|l|}{ Cyprinodontiformes } \\
\hline \multicolumn{7}{|l|}{ Poeciliidae } \\
\hline Poecilia reticulata Peters, 1859 & 14 & & & 13.0 & 23.8 & 4069 \\
\hline \multicolumn{7}{|l|}{ Labriformes } \\
\hline \multicolumn{7}{|l|}{ Cichlidae } \\
\hline Geophagus brasiliensis (Quoy \& Gaimard, 1824) & 1 & & & 136.4 & & 4065 \\
\hline Laetacara aff. araguaiae Ottoni \& Costa, 2009 & & & 2 & 22.7 & 32.5 & 4063 \\
\hline Richness & 9 & 3 & 7 & & & \\
\hline Total abundance & 44 & 9 & 59 & & & \\
\hline
\end{tabular}




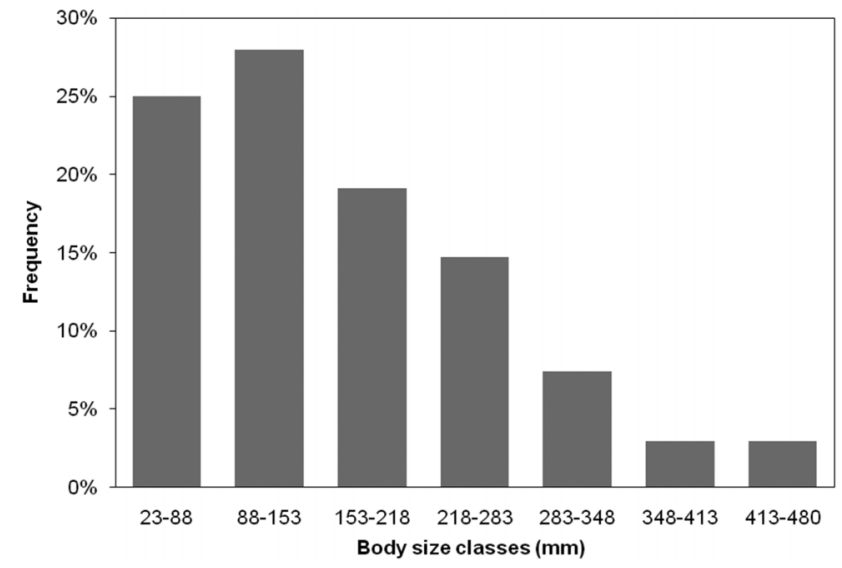

Figure 2. Frequency of occurrence of the fish species maximum body size classes in the Sapucaí-Mirim River, São Paulo State.

Figura 2. Frequência de ocorrência das classes de tamanhos máximos das espécies registradas no rio Sapucaí-Mirim, Estado de São Paulo.

species rich high taxonomical level groups (Albert et al. 2011). According to those authors, despite the exceptional species diversity, the ichthyofauna of the Neotropical region is relatively poor in higher taxonomical levels in comparison with other regions of the world. Additionally to the aforementioned fish orders, Cyprinodontiformes and Synbranchiformes complete the high taxonomical level groups found in the Sapucaí-Mirim River.

Naturally, the well-preserved Sapucaí-Mirim River fish species level composition contains part of the upper Paraná River basin diversity, representing near $20 \%$ of the species richness reported by Langeani et al. (2007) for the whole basin. As expected, the fish species inhabiting the Sapucaí-Mirim are shared with the main channel or tributaries of Grande and Paranaíba rivers, as registered by Paiva et al. (2002), Santos (2010), Pavanelli et al. (2007), Langeani \& Rêgo (2014) and Sanchez et al. (2014). But these two river basins, formers of the upper Paraná River, also share species with other great rivers that drains the Brazilian Shield plateau, as the Tocantins and São Francisco rivers. Although upper Paraná, São Francisco and Tocantins basins have some degree of endemism, justifying them as ichthyofaunistic provinces (Gery 1969), or as freshwater ecoregions (Abell et al. 2008), the existence of some sheared fish groups and species is evidence of recent reorganization of the fish fauna in these drainages, chiefly in their upper portions. According to Albert \& Carvalho (2011), the rearrangements of headwater streams, including barrier formation or drainage capture, result in vicariance or geodispersal processes that influence the Neotropical fish distribution. The geomorphological dynamic that have been occurred since Neogene and extended through Quaternary period in areas of the Brazilian Shield plateau and the biological properties of the species must be considered relevant to understand the fish composition and distribution within and among drainages. In this historical perspective, the native fish fauna here reported to the SapucaíMirim River must be considered result of these complex geological and biological events that still need to be better investigated.

Additionally, to interpret the fish assemblage structure of the Sapucaí-Mirim River is important to understand the ichthyological scenario in the Grande River basin and its environmental state. Southeastern Brazil has their natural areas intensely changed in comparison with other regions of the country. Aquatic environments in this region are mostly changed as consequence of deforestation of rivers banks and damming. The main river channel of the Grande River basin was sectioned by several dams and is actually modified in a hydroelectric complex constituted by a succession of great reservoirs (Agostinho et al. 2008). Dams may intercept the reproductive migration route of several species, interfering over the biogenic capability of the ichthyofauna in the hydrographic system, reducing the food supply and the refuge for the juvenile ichthyofauna as a whole (Agostinho et al. 1994). In this scenario of successive dams located in the main channel of great rivers, tributaries provide environmental requisites (i.e., less modified hydrodynamics and habitats features) for fish maintenance and may be important for fish diversity conservation.

In the middle Grande River drainage, the Sapucaí-Mirim River and the Uberaba River are the main tributaries of the Porto Colombia Hydroelectric Power Plant reservoir. According to Santos (2010), these two tributaries probably represent important spawning sites for the migratory fish species from this reservoir system. A large number of Neotropical fish species from reservoirs access lateral tributaries of these water bodies or other upstream lotic environments to spawn or feed, as indicated by Agostinho et al. (2008). Vazzoler et al. (1997) noted that large sized species, including Prochilodus lineatus, Salminus brasiliensis, Pimelodus maculatus Lacépède, 1803 and Leporinus obtusidens, perform great migratory dislocation to spawn at upper stretches of the tributaries of Paraná River, upstream of the Itaipú Power Plant reservoir. This pattern was also evidenced by Santos \& Formagio (2000) in the Grande River system, where a large number of medium and large sized species leave the hydroelectric reservoir during the reproductive period. In the Sapucai-Mirim River some migratory species that attain more than $400 \mathrm{~mm}$ standard length were registered, as Salminus brasiliensis, Salminus hilarii Valenciennes, 1850, Prochilodus lineatus, Pseudopimelodus mangurus (Valenciennes, 1835) and Leporinus obtusidens. The presence of the large-sized migratory species, such as Salminus brasiliensis and Prochilodus lineatus, in both sections of Sapucaí-Mirim River demonstrates the importance of this river as an alternative route for species that require long migrations to realize its reproductive processes.

On the other hand, the species composition registered in the Sapucaí-Mirim River includes groups of species with other functional attributes relative to those exhibited by large sized species. This reflects the fish morphological diversity find in the Grande and Paranaíba river basins (as shown in the studies of Paiva et al. 2002, Santos 2010, Pavanelli et al. 2007, Langeani \& Rêgo 2014 and Sanchez et al. 2014). Promptly distinction of this diversity concerns to species body size. Most of the fish species found in the Sapucaí-Mirim River is composed by small to medium-sized species, of which individuals do not perform long dislocation during their life history. Probably, populations of these species inhabit more restricted areas relative to great sized species. The small-sized species are composed chiefly by characids, parodontids, curimatids, crenuchids, heptapterids and cyprinodontiforms. These groups occur in main channels of great rivers and their distributions commonly include also small rivers and streams in the upper Paraná River basin.

In the same way, medium-sized species (e.g., characiforms of the genera Galeocharax, Hoplias, Acestrorhynchus and some anostomids; siluriforms of the genera Pimelodus, Hypostomus and the callichthyids; gymnotiforms; and cichlids) that are commonly found in main river channels may be distributed in small rivers of the Grande River basin, as observed by Oliveira et al. (2009) in tributaries of Mogi Guaçu River. Some of the medium sized species also need free impoundment river flow for their biological activities, as do the Loricariidae fishes. It is noteworthy that 
approximately $13 \%$ of the species belong to the genus Hyposto$m u s$, known to inhabit preferentially rocky bottom (Garavello \& Garavello 2004) and turbulent water environments, as found in the middle stretch studied in Sapucaí-Mirim River basin. Medium-sized species of other fish groups also indicate that Sapucaí-Mirim furnishes shelter for fish that require riverine environmental conditions, as do the anostomids of genus Leporinus and Schizodon, the serrasalmid Myleus tiete (Eigenmann \& Norris, 1900) and catfishes of the genus Pimelodus.

Comparing the mid and lower stretches of the river, the higher ichthyofauna richness found at the middle section (São Joaquim) may be explained by local aquatic conditions with hydrological characteristics similar to the original environment of this river before damming events. This middle stretch area is more heterogeneous and presents a large amount of aquatic niches viable to be explored by species presenting distinct morphological traits as, for example, bottom, nektonic and bank dwellers. The lower section (Guaíra) has the fish composition similar to that of the Porto Colombia reservoir, at Grande River (Gilmar B. Santos and Jefferson L. G. Pimenta, personal communication), which presents less species richness (approximately $30 \mathrm{spp}$.) and some non-native species, as the sciaenid Plagioscion squamosissimus, and cichlids Cichla sp. and Satanoperca pappaterra. The similarity of the fish composition among the Porto Colômbia Reservoir and the Guaíra stretch may be attributed to the geographical proximity, and probably an influence of the hydrological changes and other modifications of the original environmental characteristics allied to the lacustrine reservoir condition, which interfere in the native populations and turn feasible the colonization by non-native species. So, the differences found in species richness and composition of ichthyofauna registered in the two studied stretches of the Sapucaí-Mirim main river channel may be interpreted as result of natural distribution plus environmental changes. It is noteworthy that the habitat changes in function of human occupation are still in course in Sapucaí basin, including river damming process.

Concerning the fish composition of the three sampled creeks in Sapucaí-Mirim basin, the registered species obviously represent a fraction of the fauna distributed in streams of the upper Paraná River basin. Castro et al. (2004), studying the fish composition in streams of the Grande River basin, reported 41 species for six streams of the Sapucaí-Mirim River basin, with richness ranging from 5 to 26 species. Here we registered 17 species with richness ranging from 3 to 9 . The fauna found in the creeks was composed by small sized species and almost all of them were cited by Castro et al. (2004). Three species herein reported (Cheirodon stenodon Eigenmann, 1915, Astyanax schubarti Britski, 1964 and Laetacara aff. araguaiae Ottoni \& Costa, 2009) should be added to those authors list for the Sapucaí-Mirim River basin streams. This fact reinforces the need to increase sampling efforts in streams environments within the basin, chiefly in headwaters areas near the watersheds with adjacent river drainages.

The poorly explored Sapucaí-Mirim River showed a fish composition that includes high diversity of fish groups and encompasses much ecological diversity. It also presents rare species (as Glanidium cesarpintoi Ihering, 1928), some of them probably new to science (as Hypostomus sp.) and others that have been cited in threatened species lists. Myleus tiete figures as endangered in the national published list by Brasil (2014), and Pseudopimelodus mangurus was classified by Oyakawa et al. (2009) as vulnerable in the list of São Paulo State. The occurrence of these species and the significant fish richness registered may be attributed to the good environmental condition exhibited by the Sapucaí-Mirim River in the studied area during the sampling period.

Unfavorably, as the Sapucaí-Mirim is inserted in one of the most densely occupied region of Brazil, the anthropogenic pressure may change the properties of the fish assemblage structure in the future, chiefly because the basin is actually being dammed for hydroelectric purposes. The environmental threat includes not only damming, but also other processes that occur in the drainage area of Sapucaí-Mirim, as deforestation and urban and agricultural waste discharge. Allied to the physical chemical changes that may negatively affect the fish fauna from the basin, species introduction would represent an additional threat to native fauna. The species introduction in the Paraná system, specifically in the reservoirs, as showed by Alves et al. (2007) in the Minas Gerais State portion of the upper Paraná River basin, may bring hard deleterious effects in the native fauna. The occurrence of non native species in Sapuací-Mirim River represents that fish species introduction has been already initiated in the basin and may be intensified after the river impoundment.

The documentation of the little known ichthyofauna partially fulfills the gap of information pointed by Casatti et al. (2008) to the Sapucaí-Mirim Basin and allows to a better understand of the fish distribution in the Grande River. But only further studies on the composition, biological traits and ecology of the fish populations may attend the demand of knowledge in this area of the Grande River basin. These studies must provide basic information on the biology of the species, and serve as foundation to the application of practical actions toward fish conservation and stock maintenance of native species at this river.

\section{Acknowledgements}

Our gratitude to Luis Aparecido Joaquim by his help with the field activities. IBAMA provided license for collecting fish (number 10248-1). Fernando Apone, José Luis O. Birindelli and two anonymous referees revised the manuscript and provided useful suggestions. We thank to the Fundação de Apoio Institucional da UFSCar (FAI-UFSCAR) through the PIDICT program that provide a grant to VVC and to Conselho Nacional de Desenvolvimento Científico e Tecnológico (CNPQ) by the grants to JCG and AKO. Part of this research received financial support from FAPESP (Process 2011/50213-5) in the BIOTA/ FAPESP Program (www.biota.org.br)

\section{References}

ABELL, R., THIEME, M.L., REVENGA, C., BRYER, M., KOTTELAT, M., BOGUTSKAYA, N., COAD, B., MANDRAK, N., BALDERAS, S.C., BUSSING, W., STIASSNY, M.L.J., SKELTON, P., ALLEN, G.R., UNMACK, P., NASEKA, A., NG, R., SINDORF, N., ROBERTSON, J., ARMIJO, E., HIGGINS, J.V., HEIBEL, T.J., WIKRAMANAYAKE, E., OLSON, D., LOPEZ, H.L., REIS, R.E., LUNDBERG, J.G., PEREZ, M.H.S. \& PETRY, P. 2008. Freshwater ecoregions of the World: a new map of biogeographic units for freshwater biodiversity conservation. Bioscience 58:403-414, http:// dx.doi.org/10.1641/B580507.

AGOSTINHO, A.A., JÚlIO JR., H.F. \& PETRERE, M. 1994. Itaipu reservoir (Brazil): impacts of the impoundment on fish fauna and fisheries. In Rehabilitation of Freshwater Fisheries (I.G. Cowx, ed.). Oxford, Fishing News Book, p.171-184.

AGOSTINHO, A.A., PELICICE, F.M. \& GOMES, L.C. 2008. Dams and the fish fauna of the Neotropical region: impacts and management 
related to diversity and fisheries. Brazilian Journal of Biology 68(4): 1119-1132, http://dx.doi.org/10.1590/S1519-69842008000500019.

ALBERT, J.S. \& CARVALHO, T.P. 2011. Neogene assembly of modern faunas. In Historical biogeography of neotropical freshwater fishes (J. Albert, R.E. Reis, eds.). University of California Press, p. 119-136, http://dx.doi.org/10.3390\%2Fani1020205.

ALBERT, J.A., PETRY, P. \& REIS, R.E. 2011. Major Biogeographic and Phylogenetic Patterns. In Historical biogeography of neotropical freshwater fishes (J. Albert, R.E. Reis, eds.). University of California Press, p. 21-57.

ALVES, C.B.M., F. VIEIRA, MAGALHÃES, A.L.B. \& BRITO, M.F.G. 2007. Impacts of non- native fish species in minas gerais, brazil: present situation and propects. In Ecological and genetic implications of aquaculture activities (T. M. Bert, ed.). Springer, Dordrecht, Zuid-Holland, Netherland, p. 291-314, http://dx.doi.org/ 10.1007/978-1-4020-6148-6_16.

APONE, F., OLIVEIRA, A.K. \& GARAVELLO, J.C. 2008. Composição da ictiofauna do rio Quilombo, tributário do rio MogiGuaçu, bacia do alto rio Paraná, sudeste do Brasil. Biota Neotrop. 8(1):93-107, http://www.biotaneotropica.org.br/v8n1/pt/abstract? article + bn02208012008 (last access at 05/12/2014).

BIRINDELLI, J.L.O. \& GARAVELLO, J.C. 2005. Composição, distribuição e sazonalidade da ictiofauna do ribeirão das Araras, bacia do alto rio Paraná, São Paulo, Brasil. Comum. Mus. Ciênc. Tecnol. PUCRS, Sér. Zool. 18(1):37-51.

BRASIL, MMA. 2014. Portaria n 445, de 17 de dezembro de 2014. Diário Oficial da União, Seção 1(245):110-130.

CASATTI, L., LANGEANI, F., MENEZES, N.A., OYAKAWA, O.T. \& BRAGA, F.M.S. 2008. Peixes de Água-doce. In Diretrizes para conservação e restauração da biodiversidade no Estado de São Paulo (R.R. Rodrigues, V.L.R. Bononi, org.). Instituto de Botânica, Fapesp, São Paulo, p. 95-98.

CASTRO, R.M.C. \& CASATTI, L. 1997. The fish fauna from a small forest stream of the upper Paraná River basin, southeastern Brazil. Ichthyol. Explor. Freshwaters 7(4):337-352.

CASTRO, R.M.C., CASATTI, L., SANTOS, H.F., MELO, A.L.A., MARTINS, L.S.F., FERREIRA, K.M., GIBRAN, F.Z., BENINE, R.C., CARVALHO, M., RIBEIRO, A.C., ABREU, T.X., BOCKMANN, F.A., PELIÇÃO, G.Z., STOPIGLIA, R. \& LANGEANI, F. 2004. Estrutura e composição da ictiofauna e riachos da bacia do Rio Grande no Estado de São Paulo, sudeste do Brasil. Biota Neotrop. 4(1):1-39 http://www.biotaneotropica. org.br/v4n1/pt/abstract?article + BN01704012004 (last access at 05/ 12/2014)., http://dx.doi.org/10.1590/S1676-06032004000100006.

GARAVELLO, J.C. \& GARAVELLO, J.P. 2004. Spatial distribution and interaction of four species of the catfish genus Hypostomus Lacépède with bottom of rio São Francisco, Canindé do São Francisco, Sergipe, Brazil (Pisces, Loricariidae, Hypostominae). Braz. J. Biol. 64(3B):591-598, http://dx.doi.org/10.1590/S151969842004000400006

GERY, J. 1969. The fresh-water fishes of SouthAmerica. In Biogeography and Ecology in South America (E.J. Fittkau, J. Illies, H. Klinge, G.H. Schwabe (eds.). Dr. W. Junk N.V., Publishers, The Hague, Netherlands, p. 828-848.

GODOY, M.P. 1975. Peixes do Brasil: sub ordem Characoidei: Bacia do rio Mogi-Guaçu. Editora Franciscana, Piracicaba, vol. 1-4, 847p.

HECKEL, J.J. 1840. Johann Natterer's neue Flussfische Brasilien's nach den Beobachtungen und Mittheilungen des Entdeckers beschrieben (Erste Abtheilung, Die Labroiden). Annalen des Wiener Museums der Naturgeschichte 2:325 - 471.

LANGEANI, F., CASTRO, R.M.C., OYAKAWA, O.T., SHIBATTA, O.A., PAVANELLI, C.S. \& CASATTI, L. 2007. Diversidade da ictiofauna do Alto Rio Paraná: composição atual e perspectivas futuras. Biota Neotrop. 7(3):1-17 http://www.biotaneotropica.org. br/v7n3/pt/abstract?article + bn03407032007 (last access at 14/12/ 2014)., http://dx.doi.org/10.1590/S1676-06032007000300020.

LANGEANI, F. \& RÊGO, A.C.L. 2014. Guia ilustrado dos peixes da bacia do Rio Araguari. Grupo de Mídia Brasil Central, Uberlândia, 194 p.

OLIVEIRA, A.K. \& GARAVELLO, J.C. 2003. Fish assemblage composition in a tributary of the Mogi Guaçu River basin, Southeastern Brazil. Iheringia, Sér. Zool. 93(2):127-138, http://dx.doi.org/ 10.1590/S0073-47212003000200002.

OLIVEIRA, A.K., APONE, F., BIRINDELLI, J.L.O. \& PEREZJUNIOR, O.R. 2009. Fish, tributaries of middle Rio Mogi Guacu, upper rio Parana basin, Sao Paulo state, Southeastern Brazil. Check List 5(3):488-494, http://dx.doi.org/10.3897\%2Fzookeys.498.6896.

OYAKAWA, O.T., MENEZES, N.A., SHIBATTA, O.A., LIMA, F.C.T., LANGEANI, F., PAVANELLI, C.S., NIELSEN, D.T.B. \& HILSDORF, A.W.S. 2009. Peixes de água doce. In Fauna ameaçada de extinção no Estado de São Paulo. Vertebrados, vol. 1. (P.M. Bressan, M.C.M. Kierulff, Sugieda, AM., orgs.). Fundação Parque Zoológico de São Paulo, Secretaria do Meio Ambiente, São Paulo, p. 349-424.

PAIVA, M.P., ANDRADE-TUBINO, M.F. \&GODOY, M.P. 2002. As represas e os peixes do Rio Grande: bacia do Paraná, Brasil. Interciência, Rio de Janeiro, 78 p.

PAVANELLI, C.S., GRAÇA, W.J., ZAWADZKI, C.H., BRITSKI, H.A., VIDOTTI, A.P., AVELINO, G.S. \& VERÍSSIMO, S. 2007. Fishes from the Corumbá Reservoir, Paranaíba River drainage, upper Paraná River basin, State of Goiás, Brazil. Check List 3 (1):58-64, http://dx.doi.org/10.15560/3.1.58.

REIS, R.E., KULLANDER, S.O. \& FERRARIS, C.J. 2003. Check list of the freshwater fishes of South and Central America. EDIPUCRS, Porto Alegre, 742p.

SANCHES, B.O., BECKER, B., GOMES, P.L.A. \& SANTOS, G.B. 2014. A ictiofauna de quatro reservatórios da Cemig: caracterização das comunidades. In Condições ecológicas em bacias hidrográficas de empreendimentos hidrelétricos (M. Callisto, C.B.M. Alves, J.M. Lopes, M. A. Castro, orgs.). Companhia Energética de Minas Gerais (Cemig), Belo Horizonte, p. 185-214.

SANTOS, G.B. \& FORMAGIO, P.S. 2000. Estrutura da ictiofauna dos reservatórios do rio Grande, com ênfase no estabelecimento de peixes piscívoros exóticos. Informe Agropecuário 21(203):98-106.

SANTOS, G.B. 2010. A ictiofauna da bacia do Alto Paraná (rio Grande e rio Paranaíba). MG Biota: Boletim Técnico Científico da Diretoria de Biodiversidade do IEF-MG, Belo Horizonte: Instituto Estadual de Florestas 2(6):5-25.

SILVA, A.J.P., LOPES, R.C., VASCONCELOS, A.M. \& BAHIA, R.B.C. 2003. Bacias Sedimentares Paleozóicas e Meso-Cenozóicas Interiores. In Geologia, tectônica e recursos minerais do Brasil: texto, mapas e SIG (L.A. Bizzi, C. Schobbenhaus, R.M. Vidotti, J.H. Gonçalves, eds.). CRPM - Serviço Geológico do Brasil, Brasília, p. 55-85.

STURGES, H.A. 1926. The choice of a class interval. Journal of American Statistical Association 21(153):65-66.

VAN DER LAAN, R., ESCHMEYER, W.N. \& FRICKE., R. 2014. Family-group names of recent fishes. Zootaxa Monograph 3882 (2):1-230, http://dx.doi.org/10.11646/zootaxa.3882.1.1.

VANZOLINI, P.E. 1993. As viagens de Johann Natterer no Brasil, 1817-1835. Papéis Avulsos de Zoologia, 38(3):17-60.

VAZZOLER, A.E.A de M., SUZUKI, H.I., MARQUES, I.E. \& LIZAMA, M.A.P. 1997. Primeira maturação gonadal, períodos e áreas de reprodução. In A planície de inundação do alto rio Paraná: aspectos físicos, biológicos e socioeconômicos (A.E.A. de M. Vazzoler, A.A. Agostinho \& N.S. Hahn, eds.). Eduem, Maringá, p. 249-265.

WILEY, E.O. \& JOHNSON, G.D. 2010. A teleost classification based on monophyletic groups. In Origin and phylogenetic interrelationships of teleosts (J.S. Nelson, H.P. Schultze, M.V.H. Wilson, eds.). Verlag Dr. Friedrich Pfeil, München, p. 123-182. 